\title{
MACRO- FEATURES AND DENSITY OF VARIOUS TIMBER SPECIES FROM PAPUA
}

\section{(Tampilan Makro dan Kerapatan Beberapa Jenis Kayu dari Papua)}

\author{
MULIYANA ARIFUDIN ${ }^{1 \bowtie}$ DAN WAHYUDI $^{1}$ \\ ${ }^{1}$ Jurusan Kehutanan, Fakultas Kehutanan Universitas Papua Manokwari, Papua Barat, 98314. \\ Tlp/Fax: +62986211065. \\ ${ }^{\square}$ Penulis Korespondensi: Email: m.arifudin@unipa.ac.id \\ Diterima: 16 Juli 2020| Disetujui:12 Okt 2020
}

\begin{abstract}
Abstrak. Penelitian ini memaparkan tentang keragaman ciri-ciri makroskopis dan kerapatan beberapa jenis kayu yang paling sering digunakan di Papua. Sample kering udara dari 31 jenis kayu dengan ukuran $4 \mathrm{~cm} \times 6 \mathrm{~cm} \times 13 \mathrm{~cm}$ digunakan untuk pengukuran kerapatan kayu dan pengamatan makroskopis yang meliputi warna kayu, orientasi serat dan tekstur kayu.Hasil penelitian menunjukkan bahwa keputih-putihan dan kuning ke kuning kecoklatan merupakan warna yang dominan dari sebagian besar kayu yang dipanen dari hutan tropis Papua. Orientasi serat pada kebanyakan species adalah lurus, sedangkan teksturnya sedang. Terkait dengan kerapatan kayu, Kayu Sowang (Xantostenum spp) merupakan kayu yang paling berat dengan kerapatan sebesar 1,25 $\mathrm{g} / \mathrm{cm}^{3}$, sedangkan kayu pulai (Alstonia scholaris). Jadi mayoritas jenis kayu dari hutan Papua yang telah diteliti dikategorikan ke dalam jenis-jenis kayu berkerapatan rendah (light class species). Pulp dan kertas, vinir, plywood, flooring, bahan mebel, indoor furniture dan perkakas berbahan kayu merupakan potensi penggunaan dari beberapa jenis kayu yang telah diteliti.

Kata kunci: sifat makroskopis, kerapatan kayu, jenis kayu papua, pemanfaatan kayu

Abstract. This research highlights diversity of macro-features and density of major timber species from Papua. Thirty-one species of air-dried timber with sample size of $13 \mathrm{~cm} \times 6 \mathrm{~cm} \times 4 \mathrm{~cm}$ gathered across Papua were used for density measurement and macro-features observation, cover of colors, grain orientation, and wood texture. The results showed that whitish and straw to yellow brown are dominant color of timber mostly harvested from Papua tropical forest. Their grain orientations are mostly straight, while their textures are medium. With regard to their density, Xantostemum spp is the heaviest timber having density of $1,25 \mathrm{~g} / \mathrm{cm}^{3}$ while Alstonia scholaris is the lightest species of timber with density of $0.29 \mathrm{~g} / \mathrm{cm}^{3}$. Therefore, majority Papua 's timber species studied are classified into light class species or low density timbers. Pulp and paper, veneer, plywood, flooring, meubels, indoor urnitures and handles or woody utensils are the potential uses of these timber species.
\end{abstract}

Keywords: macro-features, density, Papua's timber species, papua tropical forest, wood utilization

\section{INTRODUCTION}

Papua is western-half of New Guinea Island that is rich in flora and fauna resources, including wood or timber species. It is highlighted that timber species in Papua consisting of Papua and Papua Barat Provinces are about of 400 but only 100 timber species are commercially harvested and traded. Papua still has a great number of wood species that are still lesser known species commercially but they had been used traditionally and locally for various needs and purposes of utilizations from one generation to generation by the local people. However, fundamental charateristics of these species are still unrecorded or unexplored yet (Wahyudi et al. 2014). Sowang (Xanthosthemum sp) is an example of timber that has been used widely and preferably for building houses and bridges by local people around Sentani Lake Papua (Wilujeng and Simbiak 2015), but the data of its fundamental properties have not 
been explored or even published. The fundamental characteristation of physical, chemical and mechanical wood properties play a key roles on the advanced utilization of timbers. Timbers used for structural purposes are significantly influenced by their density. Therefore, most tropical timber are graded based on their density (Haygreen and Bowyer 1982).

Demands of timber used for construction and building materials has increased recently but the supply of commercial wood species has decreased due to their limited availability because of over-exploitation and limited option of timber preferences mainly at local customers, markets and utilizations (Wahyudi et al. 2014). It has been highlighted that two favorable sawn timbers for market and demand at Papua region are Merbau (Instia spp) and Matoa (Pometia spp) mainly for construction and building material, while for furniture associated products are Lingua (Pterocarpus indicus) and Dragon (Dracontomellum edule) for the first preference (Wahyudi et al. 2014). At Manokwari town as the capital city of Papua Barat province today, for example, these demanding sawn timbers are supplied from outsite of Manokwari region or neighbouring regency of Bintuni, Wasior and Manokwari Selatan. Therefore, the prices are soaring dramatically. Price of local grade of chain sawn timber of Merbau (Instia spp) for one meter cubic $\left(1 \mathrm{~m}^{3}\right)$ is from IDR $350,000.00$ in 2002 to IDR 5,000,000.00 in 2016 due to huge demand for housing, governmental offices, school, and furniture associated products. Therefore, promoting and domesticating of other timber species which are unknown species or lesser utilized ones is one of the solutions to address the problem of limitation in timber supply and preferences as well as to give an alternative option to the local markets or customers.

The use of lesser known species as alternative, therefore, has increasingly attracted the interests of wood processing industries to generate various wood products because they have similar characteristics with those wood which are well known in wood trades (Ogata et al. 2008). Sempur (Dillenia $s p$ ) and Watergum (Syzygium sp) are two lesser used timber species recommended for indoor construction as their technical attributes are comparable to Matoa (Pometia spp) and provide an optional substituent timber for local market at Papua (Wahyudi et al. 2014).

Proper utilization of timber species requires fundamental understanding on wood properties such as density and macro-features (Haygreen and Bowyer 1982). Many sudies have improved methods to identify wood species based on their natural properties, such as determination matrix system (Ruffinatto et al. 2015) and computerizing non linear feature of wood species for recognition system (Yusof et al. 2013). Macro-features of wood are quickly wood identification based on readily visible characteristics of color, density, grain pattern, and wood texture (Tsoumis 1968). Therefore, this paper describes fundamental macro-features and density of thirty one timber species from Papua, and provides scientific support for advanced and proper utilization based on their density and macro-features. The output of this paper is expected to provide information about the end-uses of the timber species studied for alternative timber species and preferences to local market and demands in Papua and Papua Barat provinces.

\section{MATERIALS AND METHODS}

\section{Sample Collection and Preparation}

Thirty one samples of air dried timber species of our laboratory collection were collected from Papua's natural forests. Each timber was cut into small sample with $4 \mathrm{~cm}$ in tangential x $6 \mathrm{~cm}$ in radial and $13 \mathrm{~cm}$ in cross section respectively in sizes. Mostly, the samples consists of both sapwood and heartwood at different proportion and few sample are devoid of either sapwood or heartwood.

\section{Macro-Feature Observation and Density Measurement}

Wood color was identified with naked eyes using the color charts (Ilic 1990). Grain directions and wood texture were identified using a hand lens (loupe) with 10x magnifying. Wood density $\left(\mathrm{g} / \mathrm{cm}^{3}\right)$ was measured using method developed by Siauw (1971) in which the density $\left(\mathrm{g} / \mathrm{cm}^{3}\right)$ is the 
ratio of weight $(\mathrm{g})$ to its volume $\left(\mathrm{cm}^{3}\right)$ at airdried moisture content. The wood density was grouped into two types of classifications (Ruffinatto et al. 2015) for hardwood and general wood species density (Csanady et al. 2015).

\section{RESULT AND DISCUSSION}

Variety of wood macro-features, their density, botanical and local name as well as family of the most-harvested timber species from Papua are summarised in Tabel 1. The results indicate family Annacardiaceae and Myrtaceae representing five and three timber species respectively are mostly harvested commercially. These timbers are classified into that macro-features and density of thirty one timber species collected from Papua examined are tabulated in the Table 1.

The color of timber varies considerably from one species to another. Even within a tree species, sapwood color can be different from heartwood. In general, heartwood is darker-colored than sapwood, depending on the type and quantity of extractive contained in a wood species. For some species, however, the color between sapwood and heartwood is indistinctive.

It can be seen from the Table 1 that 14 timber species belong to Feature 1 class, according to wood color classification by Ilic (1990), in which the heartwood color ranges between straw, whitish, pale brown and yellow brown. Pale color of heartwood indicates that all the extractives are not in dark color. Some species of timber do not have pigmented extractives in relation to heartwood formation but it does not mean that they are lack of durability (Hoadley 2000). Those species listed in Feature 1 color class are usually called with "white wood" for timber trade term or lighter-heartwood species suitable for making pulp and paper, veneer, plywood, flooring, meubels, indoor furnitures and handles or woody utensils. These wood species are good material to made of chopsticks, toothpicks as and wood shavings (Hon and Minemura 2001).

Those timber listed in Feature 2 and 4 have darker color of heartwood than those in Feature 1, exhibiting brown to dark brown heartwood without red tints (feature 2) and also combination with other colors (feature 2 and 4). These species are generally used for construction works (including heavy construction such as building, bridge and marine-freshwater construction), interior and exterior joinery, furniture, cabinet work and so on. Feature 3 shows species which have pale to dark brown with pink or red tintsheartwood, such as reddish brown. Generally, the utilization of wood in this class almost similar to those in Class Feature 2 and Feature 2 and 4 . The possible utilizations are building materials, ceiling board, wall panelling, furniture, interior doors, etc. Red wood also can be used as decorative materials in house construction, and also for crafting, for instruments and for art objects (Hon and Minemura 2001). The only one wood species which is listed in Feature 4 class is Xanthostemum spp or is locally called Sowang wood. The color is very dark brown to almost black, indicating its higher extractive content. Extractives in the heartwood can affect the utilization of the wood for technological application (Rowell 2005). This wood is suitable used as heavily constructional materials for buildings, such as bridge and houses.

Wood grain is defined as the direction of wood elements (Tsoumis 1968). In this study, grain direction is divided into two types, straight and cross grain, resepectively. Spiral, interlocked, diagonal and wavy are categorized as cross grain. Acording to Table 1 , the majority of timber species from Papua has straight grain, while only 10 species have cross grain. Straight-grained timbers are generally chosen for construction due to its strenght, easier for wood working and machining with minimal complication. In fact, some species have been used for buiding houses, bridges, power poles, flooring and other constructional workings (Instia spp, Pometia spp) as well as furniture associated products (Dracontomellum edule, Pterocarpus sp, Palaquium sp) and pole of wooden house on the Sentani Lake (Xantostemum spp). Woods with cross grain have reduced strength but generally tend to have aesthetic values. These are suitable used for indoor meubels and furnitures. Interlocked grain can influence the production of smooth 
surface during wood machining (Csanady 2015).

With regards to wood texture, Table 1 shows that 14 timber species have moderate texture, 11 species have fine texture and only 6 timber species are coarse texture. Wood texture influences their wood working and finishing properties. Wood with fine to moderate textures are preferred in secondary wood processing industries. Coarse texture of a wood is addressed to the presence of massive wood pharenchyma. This can cause particular difficulties in wood processing, such as planing, milling, boring, and turning as well as in producing smooth finishing (Csanady 2015).

Wood density for the thirty one timber species from Papuan forest range from 0,29 to $1,25 \mathrm{~g} / \mathrm{cm}^{3}$ (Table 1). The wood species studied locally called Sowang (Xanthosthemum spp) has the highest density and is categorized as very heavy timber for classification 1 or heavy wood for classification 2. This species is heavier than the well known species of traded timber mark of Papua Merbau (Intsia spp) even for New Guinea. It implies that Sowang has higher strength properties. Besides, the color of this wood is very dark brown to almost black
(Table 1). This indicates that heavy timber is naturally durable as explained previously in the wood color. For these reasons, the local people use this timber as main option material for heavy contructions of houses and bridges from generation to generation. Other timber species which are included in heavy class of timber are Coordesiodendron sp, Intsia spp, Eucalyptus sp, Homalium sp and Syzygium sp. The second and the third species are well known in wood trade as constructional materials due to their strength as well as their natural durability. Eleven timber species have medium or moderate density of range from $0,54-0,74 \mathrm{~g} / \mathrm{cm}^{3}$. They are usually processed in sawmill for heavy and light constructions, meubels, furnitures and flooring. Some of them are commonly used for making traditional ship and part of bridges. Of the timber species studied, almost a half have low density (light class) and two timber species have the lowest density (very light class) as been also indicated with lighter color of heartwood (Table 1). Light hardwoods are potentially used for high-class joinery works, cabinet making, furnitures and decorative panelling (Csanady 2015). Other possible uses are for making pulp and paper, veneer, plywood, handles or woody utensils, chopsticks and toothpicks. 
Malcro-features and density of major timber species of Papua

\begin{tabular}{|c|c|c|c|c|c|c|c|c|c|c|c|c|}
\hline \multirow[t]{2}{*}{ No } & \multicolumn{2}{|l|}{ Name } & \multirow[t]{2}{*}{ Family } & \multicolumn{4}{|c|}{ Color } & \multirow{2}{*}{$\begin{array}{c}\text { Grain } \\
\text { Directio } \\
n\end{array}$} & \multirow[t]{2}{*}{ Texture } & \multicolumn{3}{|c|}{ Density and Classification } \\
\hline & Botanical & Local & & Sapwood (S) & $\begin{array}{l}\text { Heartwood } \\
\qquad(\mathrm{H})\end{array}$ & $\begin{array}{c}\text { S-H } \\
\text { difference }\end{array}$ & Feature & & & $\left(\mathrm{g} / \mathrm{cm}^{3}\right)$ & 1 & 2 \\
\hline 1 & Accacia mangium & Akasia & Mimosoideae & yellow brown & brown & distinct & 2 & SG & $\mathrm{M}$ & 0,57 & moderate & light \\
\hline 2 & Accacia decurens & Akasia & Mimosoideae & straw & brown & distinct & 1 & SG & $\mathrm{M}$ & 0,74 & moderate & medium \\
\hline 3 & $\begin{array}{l}\text { Aleurites } \\
\text { mollucana }\end{array}$ & Kemiri & Euphorbiaceae & yellow brown & $\begin{array}{l}\text { yellow } \\
\text { brown }\end{array}$ & indistinct & 1 & CG & $\mathrm{F}$ & 0,40 & light & light \\
\hline 4 & Alstonia scholaris & Pulai & Apocynaceae & whitish & whitish & indistinct & 1 & SG & $\mathrm{C}$ & 0,29 & very light & light \\
\hline 5 & $\begin{array}{l}\text { Anthocephalus } \\
\text { cadamba }\end{array}$ & Jabon & Rubiaceae & straw & $\begin{array}{l}\text { yellow } \\
\text { brown }\end{array}$ & distinct & 1 & $\mathrm{SG}$ & $\mathrm{F}$ & 0,44 & light & light \\
\hline 6 & $\begin{array}{l}\text { Antiaristoxicaria } \\
\text { Lesch }\end{array}$ & Antiaris & Moraceae & yellow brown & $\begin{array}{l}\text { reddish } \\
\text { brown }\end{array}$ & distinct & 3 & SG & M & 0,59 & moderate & light \\
\hline 7 & Araucaria klinki & Araukaria & Araucariaceae & straw & straw & indistinct & 1 & SG & $\mathrm{F}$ & 0,48 & light & light \\
\hline 8 & $\begin{array}{l}\text { Cinamomum } \\
\text { culilawan }\end{array}$ & Lawang & Lauraceae & whitish & whitish & indistinct & 1 & $\mathrm{CG}$ & $\mathrm{M}$ & 0,34 & light & light \\
\hline 9 & $\begin{array}{l}\text { Koordersiodendro } \\
n \text { pinnatum }\end{array}$ & Bugis & $\begin{array}{l}\text { Annacardiacea } \\
\text { e }\end{array}$ & brown & dark brown & distinct & 2 & SG & $\mathrm{M}$ & 0,94 & heavy & heavy \\
\hline 10 & Dillenia spp & Simpur & Delliniaceae & brown & brown & indistinct & 2 & SG & $\mathrm{M}$ & 0,58 & moderate & light \\
\hline 11 & $\begin{array}{l}\text { Dracontumelum } \\
\text { edule }\end{array}$ & Dao & $\begin{array}{l}\text { Annacardiacea } \\
\text { e }\end{array}$ & straw & $\begin{array}{l}\text { yellow } \\
\text { brown }\end{array}$ & distinct & 1 & SG & $\mathrm{F}$ & 0,54 & moderate & light \\
\hline 12 & $\begin{array}{l}\text { Elmerrillia } \\
\text { Papuana }\end{array}$ & Elmerrillia & Magnoliaceace & orange brown & $\begin{array}{l}\text { orange } \\
\text { brown }\end{array}$ & indistinct & 2,4 & SG & $\mathrm{F}$ & 0,49 & light & light \\
\hline 13 & Eucalyptus alba & Eukaliptus & Myrtaceae & orange brown & dark brown & distinct & 2 & CG & $\mathrm{F}$ & 0,68 & moderate & medium \\
\hline 14 & $\begin{array}{l}\text { Eucalyptus } \\
\text { deglubta }\end{array}$ & Eukaliptus & Myrtaceae & reddish brown & $\begin{array}{l}\text { reddish } \\
\text { brown }\end{array}$ & indistinct & 3 & $\mathrm{CG}$ & $\mathrm{C}$ & 0,79 & heavy & medium \\
\hline 15 & Eugenia spp & $\begin{array}{l}\text { Jambu } \\
\text { Hutan }\end{array}$ & Myrtaceae & whitish & whitish & indistinct & 1 & SG & $\mathrm{M}$ & 0,41 & light & light \\
\hline 16 & Gmellina spp & Gmellina & Verbenaceae & pale brown & pale brown & indistinct & 1 & SG & $\mathrm{F}$ & 0,47 & light & light \\
\hline
\end{tabular}




\begin{tabular}{|c|c|c|c|c|c|c|c|c|c|c|c|c|}
\hline 17 & $\begin{array}{l}\text { Homalium } \\
\text { foetidum (Roxb.) } \\
\text { Benth }\end{array}$ & Kayu Merah & Flacourtiaceae & reddish brown & $\begin{array}{l}\text { reddish } \\
\text { brown }\end{array}$ & indistinct & 3 & $\mathrm{SG}$ & $\mathrm{M}$ & 0,77 & heavy & medium \\
\hline 18 & Intsia bijuga & $\begin{array}{l}\text { Merbau/ } \\
\text { Besi }\end{array}$ & $\begin{array}{l}\text { Caesalpinioide } \\
\text { ae }\end{array}$ & $\begin{array}{c}\text { chocolate } \\
\text { brown }\end{array}$ & dark brown & distinct & 2 & $\mathrm{SG}$ & $\mathrm{M}$ & 0,85 & heavy & heavy \\
\hline 19 & $\begin{array}{l}\text { Mastixiodendron } \\
\text { pachyclados }\end{array}$ & Lancat & Rubiaceae & reddish brown & $\begin{array}{l}\text { reddish } \\
\text { brown }\end{array}$ & indistinct & 3 & $\mathrm{SG}$ & $\mathrm{F}$ & 0,68 & moderate & medium \\
\hline 20 & Myristica spp & Mendarahan & Myristicaceae & orange brown & $\begin{array}{l}\text { orange } \\
\text { brown }\end{array}$ & indistinct & 2,4 & $\mathrm{SG}$ & $\mathrm{M}$ & 0,46 & light & light \\
\hline 21 & $\begin{array}{l}\text { Octomeles } \\
\text { sumatrana }\end{array}$ & Binuang & Datiscaceae & straw & $\begin{array}{l}\text { yellow } \\
\text { brown }\end{array}$ & distinct & 1 & $\mathrm{CG}$ & $\mathrm{F}$ & 0,33 & light & light \\
\hline 22 & $\begin{array}{l}\text { Palaquium } \\
\text { amboinense }\end{array}$ & Nyatoh & Sapotaceae & pale brown & $\begin{array}{l}\text { orange } \\
\text { brown }\end{array}$ & distinct & 2,4 & SG & $\mathrm{M}$ & 0,55 & moderate & light \\
\hline 23 & $\begin{array}{l}\text { Pharaserianthes } \\
\text { falcataria }\end{array}$ & Sengon & Mimosoideae & whitish & pale brown & distinct & 1 & $\mathrm{CG}$ & $\mathrm{C}$ & 0,31 & light & light \\
\hline 24 & $\begin{array}{l}\text { Pterygotha } \\
\text { horsfieldii }\end{array}$ & Bipa & Sterculiceae & straw & straw & indistinct & 1 & $\mathrm{CG}$ & $\mathrm{M}$ & 0,38 & light & light \\
\hline 25 & Pometia coriace & Matoa & Sapindaceae & brown & $\begin{array}{l}\text { orange } \\
\text { brown }\end{array}$ & distinct & 2,4 & $\mathrm{CG}$ & $\mathrm{C}$ & 0,72 & moderate & medium \\
\hline 26 & Pometia pinnata & Matoa & Sapindaceae & reddish brown & $\begin{array}{l}\text { reddish } \\
\text { brown }\end{array}$ & indistinct & 3 & SG & $\mathrm{F}$ & 0,57 & moderate & light \\
\hline 27 & $\begin{array}{l}\text { Pterocarpus } \\
\text { indicus }\end{array}$ & Linggua & Papilionoideae & pale brown & $\begin{array}{l}\text { reddish } \\
\text { brown }\end{array}$ & distinct & 3 & $\mathrm{CG}$ & $\mathrm{M}$ & 0,55 & moderate & light \\
\hline 28 & $\begin{array}{l}\text { Spathodea } \\
\text { campamulata }\end{array}$ & Panchut & Bignoniceae & straw & straw & indistinct & 1 & $\mathrm{CG}$ & $\mathrm{F}$ & 0,29 & very light & light \\
\hline 29 & Spondias dulcis & Spondias & Anacardiaceae & whitish & whitish & indistinct & 1 & $\mathrm{SG}$ & $\mathrm{C}$ & 0,31 & light & light \\
\hline 30 & $\begin{array}{l}\text { Syzygium } \\
\text { versteegii }\end{array}$ & Watergum & Myrtaceae & brown & brown & indistinct & 2 & $\mathrm{SG}$ & $\mathrm{C}$ & 0,76 & heavy & medium \\
\hline 31 & $\begin{array}{l}\text { Xanthostemum } \\
\text { spp }\end{array}$ & Sowang & Myrtaceae & $\begin{array}{c}\text { very dark } \\
\text { brown }\end{array}$ & almost black & distinct & 4 & $\mathrm{SG}$ & $\mathrm{M}$ & 1,25 & $\begin{array}{l}\text { very } \\
\text { heavy }\end{array}$ & heavy \\
\hline $\begin{array}{l}1 \\
2 \\
3 \\
4\end{array}$ & & & & & & & & & & & & \\
\hline
\end{tabular}




\section{Note: \\ 1. Feature: $1=$ whitish, pale brown, pale yellow and straw. Heartwood color ranges from silvery-white, yellowish-white, to pale brown. $2=$ definitive brown to dark brown \\ $3=$ pink or red tints, including red brown, darker brown with pink or red tints. \\ $4=$ other colors: black, purple, bright yellow, orange, etc \\ $5=$ streaky (variation in color of heartwood extractives, not because of figure caused by anatomical features.}

\section{Grain Direction: $\mathrm{SG}=$ Straight Grain; $\mathrm{CG}=$ Cross Grain}

3. Texture: $\mathrm{C}=$ Coarse; $\mathrm{M}=$ Moderate; $\mathrm{F}=$ Fine

4. Density Classification: $1=$ for hardwood species density

$2=$ for general wood species density 


\section{CONCLUSION}

The color of thirty one timber species from Papua studied here are predominantly whitish, straw to yellow brown, which are categorized as Feature 1 in wood color classification. Grain direction of majority is straight grain and medium is the dominan texture. The Papuan timber species studied have a wide range of densities, in which Xanthostemum sp has the highest density of $1,25 \mathrm{~g} / \mathrm{cm}^{3}$ (very heavy), while Alstonia scholaris has the lowest density of $0,29 \mathrm{~g} / \mathrm{cm}^{3}$ (very light). Almost a half of timber species from Papua are categorized as light class or having low density. They are potentially used for making pulp and paper, veneer, plywood, flooring, meubels, indoor furnitures and handles or woody utensils.

\section{REFERENCES}

Csanady E, Endre M and Laszlo T. 2015. Quality of machined wood surface. Springer International Publishing. Switzerland. pp. 59, 109-119, 183-184.

Haygreen JG and Bowyer JL. 1982. Forest products and wood science. An Introduction. The Iowa State University Press USA. pp. 196-217

Hoadley RB. 2000. Understanding wood. A craftman's guide to wood technology. The Taunton Press. pp.9-18.

Hon DNS and Minemura N. 2001. Color and discoloration. In Hon, D.N.S. and Shiraishi, N. Wood and cellulosic chemistry, second edition, revised and expanded. Marcel Dekker Press. USA. pp 385-395.

Ilic J. 1990. The CSIRO makro key for hardwood identification. Division of Forestry and Forest Product. CSIRO Australia. pp. 14-27.

Ogata K, Fujii T, Abe H and Bass P. 2008. Identification of the timbers of Southeast Asia and the Western Pacific. Forestry and
Forest products Research Institute, Japan. Kaiseisha Press. pp. 8-366.

Ruffinatto F, Crivellaro A and Wiedenhoft AC. 2015. Review of macroscopic features for hardwood and softwood identification and a proposal for a new character list. IAWA Journal $36 \quad(2): 208-241$. DOI: 10.1163/22941932-00000096.

Siauw JF. 1971. Flow in wood. Syracuse University Press. New York. pp. 7-9.

Tsoumis G. 1968. Wood as raw material. Source, structure, chemical composition, growth, degradation and identification. Pergamon Press. pp. 19-24.

Wahyudi, Susilo BE and Makrus. 2014. Machining properties of two lesser used timber from West Papua. J. Ilmu dan Teknologi Kayu Tropis 12 (1):74-81. (In Indonesian) Available from: https://www.academia.edu/10570457/Sifat Permesinan Dua Jenis Kayu Kurang Dim anfaatkan_Asal_Papua_Barat_Machining_Pr operties of Two Lesser Used Timber fro m_West_Papua [accessed 18 August 2017]

Wilujeng S and Simbiak M. 2015. Morphological characterization of Xanthostemon novoguineensis Valeton (Myrtaceae) from Papua [online]. Proceeding of Indonesian Association of Biodiversity 1(3): 466-471. DOI: 10.13057/psnmbi/m010315.

Yusof R, Khalid $M$ and Khairuddin ASM. 2013. Application of kernel-genetic algorithm as non linear feature selection in tropical wood species recognition system. Journal of Computer and Electronics in Agriculture 93:68-77. Available from:

http://www.sciencedirect.com/science/article/pi i/S0168169913000227 [accessed 1 December 2016]. 